\title{
Los procesos de emprendimiento en Colombia y su incidencia en los sectores productivos
}

Entrepreneurship processes in Colombia and their impact

on the productive sectors

Os processos de empreendedorismo na Colômbia e sea incidência nos setores produtivos

\section{López-Rodríguez,}

Campo Elías

Corporación Universitaria Minuto de Dios UNIMINUTO, Bogotá, Colombia

E-mail:clopezr3@uniminuto.edu.co

\section{Cristancho-Triana,}

Gerson Jaquin

Universidad ECCl, Bogotá, Colombia.

E-mail: gcristanchot@ecci.edu.co

\author{
Cabrera-Jiménez, \\ Manuel Fernando \\ Universidad ECCl, Bogotá, Colombia. \\ E-mail:mcabreraj@ecci.edu.co
}

Fecha de recepción: 11/03/2020 Fecha de aceptación: 20/08/2020

Palabras clave

- Emprendimiento

- Desarrollo regional

- Sectores productivos

- Innovación

- Emprendedor

\section{Resumen}

El emprendimiento es una actividad generadora de riqueza, puesto que el conocimiento, la creatividad y la innovación de ideas emprendedoras, beneficiarán la sociedad y a su vez al sector productivo. Por medio de una revisión de la literatura se reconoce la evolución de los procesos emprendedores en Colombia y su incidencia en sus sectores productivos. Se evidencia que el sector con menor stock de empresas es el de construcción y el de mayor corresponde al sector de comercio, el sector servicios es el de mayor volatilidad, mientras que el sector industria es el más estático. Los servicios comienzan a tener un descenso paulatino frente al desarrollo de emprendimientos futuros, siendo el consumo el sector clave en términos creación de empresas para el contexto colombiano.

\footnotetext{
Abstract

TEntrepreneurship is a wealth-generating activity since knowledge, creativity and innovation of entrepreneurial ideas will benefit society and, in turn, the productive sector. Through a review of the literature, the evolu-
} 
Keywords

- Entrepreneurship

- Regional development

- Productive sectors

- Innovation

- Entrepreneur

Palavras-Chave

- Empreendedorismo

- Desenvolvimento regional

- Setores produtivos

- Inovação

- Empreendedor. tion of entrepreneurial processes in Colombia and their impact on the country's productive sectors are recognized. It is evident that the sector with the smallest stock of companies is the construction sector and the one with the highest level is the commercial sector; the services sector is the one with the highest volatility, while the industrial sector is the most static. The services sector is experiencing a gradual decline compared to the development of future ventures, with consumption being the key sector in terms of business creation for the Colombian context.

\section{Resumo}

0 empreendedorismo é uma atividade geradora de riqueza, já que o conhecimento, a criatividade e a inovação de ideias empreendedoras beneficiarão a sociedade e, ao mesmo tempo, ao setor produtivo. Por meio de uma revisão da literatura, reconhece-se a evolução dos processos empreendedores na Colômbia e sua incidência em seus setores produtivos. Evidencia-se que 0 setor com menor estoque de empresas é o setor da construção e, o maior, corresponde ao setor do comércio, o setor de serviços é 0 de maior volatilidade, enquanto 0 setor da indústria é o mais estático. Os serviços começam a declinar gradualmente frente ao desenvolvimento de empreendimentos futuros, sendo 0 consumo 0 setor chave para 0 contexto colombiano em termos de criação de empresas. 